\title{
Activity budget patterns in family-group and solitary territorial male guanacos
}

\author{
Patrones de presupuesto de actividad de guanacos machos territoriales en \\ grupos familiares y solitarios
}

JULIE K. YOUNG ${ }^{1} \&$ WILLIAM L. FRANKLIN ${ }^{2}$

\begin{abstract}
Department of Natural Resource Ecology and Management, 124 Science II, Iowa State University, Ames, Iowa 50011, USA ${ }^{1}$ Current address: Department of Forest, Range, and Wildlife Sciences, Utah State University, Logan, Utah 84322, USA

${ }^{2}$ Current address: Professor Emeritus, $4048^{\text {th }}$ Street North West, Nora Springs, Iowa 50458, USA Corresponding author: e-mail: jky@cc.usu.edu
\end{abstract}

\begin{abstract}
We observed behavioral patterns of territorial male guanacos (Lama guanicoe) in Torres del Paine National Park, Chile. Both solo territorial males and family-group territorial males were observed to compare the activity time budgets of males $(\mathrm{n}=23)$ in different social groups and habitats. We found no difference in the activity time budgets of males based on social group type, total number of females or all guanacos present, or age of territorial males. Males, in all categories, spent most of their time foraging $(65 \%$ of overall time budget). There was a significant difference in time spent in aggressive and in miscellaneous (defecation, alertness to observer, scratching) activities based on habitat type; most aggressive encounters and miscellaneous activity occurred on hilltops of areas dominated by mata barrosa shrubs (Mulinum spinosum). It is likely that territorial male guanaco behaviors are related to the resources defended rather than to any direct ability to attract potential mates.
\end{abstract}

Key words: guanaco, activity budget, territorial behavior, resource-defense.

\section{RESUMEN}

Observamos patrones de comportamiento de guanacos machos territoriales (Lama guanicoe) en el Parque Nacional Torres del Paine, Chile. Comparamos el presupuesto de actividad de machos solos y en grupos familiares $(n=23)$ en diferentes hábitat. No encontramos diferencias en los presupuestos de actividad de machos basados en el tipo de grupo social, número total de hembras o número total de guanacos presentes, o la edad de los machos territoriales. Guanacos macho en todas las categorías asignaron alrededor de $65 \%$ de su actividad a forrajeo. Por otra parte, detectamos una influencia del tipo de hábitat sobre el tiempo asignado a interacciones agresivas y misceláneas (defecación, vigilancia al observador, rasguñando); las interacciones agresivas y conductas misceláneas fueron más frecuentes en cimas de colinas de áreas dominadas por el arbusto mata barrosa (Mulinum spinosum). Es probable que el comportamiento de los machos territoriales del guanaco esté relacionado a los recursos defendidos más que a una habilidad para atraer hembras y aumentar el éxito de apareamiento.

Palabras clave: presupuesto de actividad del guanaco, comportamiento territorial, defensa del recurso.

\section{INTRODUCTION}

Behavioral patterns of polygynous, territorial male ungulates can be influenced by external factors. Predator avoidance, foraging, and reproductive needs may influence male activity budgets. This variation in behavior can allow a male to attract mates, secure a territory, reduce predation risk, and increase foraging efficiency (Jarman 1974, Lipetz \& Bekoff 1982, Walther et al. 1983, Goldsmith 1990). While some territorial ungulate males budget a large proportion of time to attract mates (Estes 1991), others attract mates through the resources defended (Emlen \& Oring 1977) and spend a disproportionate amount of time foraging (Maher 1991, Colman et al. 2001, Shi et al. 2003).

Territorial male guanacos (Lama guanicoe) in Torres del Paine National Park, Chile, defend 
resources to attract mates through resourcedefense polygyny (Franklin 1982, 1983). From spring through late autumn, reproductive-aged males are found in one of three social group types: family groups, solo, and male groups (Franklin 1983, Ortega \& Franklin 1995). Territorial males actively defend their space but there is no evidence that they defend or herd females that enter their territories.

Family-group territorial males establish a territory, which is occupied by reproductiveaged females, yearlings and chulengos $(<1$ year old). The females, yearlings, and chulengos present are not necessarily related to the territorial males. Solo territorial males have an established territory with females and young rarely present. Average territory size is $24.9 \pm$ 1.6 ha, with no difference in size between solo and family-group territorial males (Young \& Franklin 2004). The open habitat and small territory size results in high visibility among neighboring territorial male guanacos. The remaining non-territorial males are found in male groups (Franklin 1982, 1993, Ortega \& Franklin 1995).

Male guanacos that contribute reproductively to the population are almost always found in family groups. Only under rare circumstances do solo territorial males or males in male groups have an opportunity to mate (Jurgensen 1985). Over $70 \%$ of territorial male guanacos exhibit a high degree of site-fidelity, returning to the same territorial location each breeding season for up to eight consecutive years (Young \& Franklin 2004). Territorial males also typically remain in the same social group between territorial years, although up to $19 \%$ of solo territorial males become familygroup territorial males (Young \& Franklin 2004). Females move freely between territories within the breeding season, but it is unclear if females return to specific male territory locations between years.

Although resource-defense is evident (Franklin 1983), we observed that neighboring males under similar conditions of habitat (e.g., equivalent dominant plant and slope characteristics) have different mating success. We, therefore, believe that a secondary strategy could be playing a role in the outcome of mating success. We predict that solo territorial males will behave differently than family-group territorial males. The lack of mating opportunities, potential to change social status, and the near absence of other guanacos present likely influence the behavior of solo territorial males. Specifically, we predict family-group territorial males will spend more time alert and less time foraging than solo territorial males. Furthermore, we predict that predation risk will influence alert behavior of all males based on the time of day, resulting in males exhibiting more alert behavior in the morning when predation is more likely to occur (Frankli et al. 199).

We observed territorial male guanacos to examine behavioral patterns of solo and familygroup territorial males. Our main objectives were: (1) to determine if there were differences in the activity budgets of territorial males based on social group type, and (2) to identify other factors, such as age of territorial guanaco, time of day, and number of females present, that may influence behavioral patterns of territorial males.

\section{MATERIAL AND METHODS}

We collected data on previously tagged, known-age territorial male guanacos in Torres del Paine National Park, Chile (Franklin \& Johnson 1994). The park is home to one of the largest wild populations in existence (Torres 1985, 1992). These guanacos are habituated to humans, which made observing natural behaviors at close range possible. Observations were conducted by three field researchers during the territorial season (October 1998March 1999) between the hours of 09:30 and 16:00. Males were selected at random and observed for two, 15-min focal samples (Altmann 1974). The observer sat next to a rock, bush, or along a slope to minimize obtrusiveness and waited up to $5 \mathrm{~min}$ to start collecting data so that the focal male adjusted to the observer's presence. Most observations were made within $100-300 \mathrm{~m}$ of the focal male. The observer took a five-minute break between each focal sample. Focal samples were treated as independent samples because an individual's behavior typically varied between sampling periods and some males were observed only one time because they left their territory (i.e., defensive pursuit of neighboring male) before the second sampling period began.

A total of 23 males were observed during 120 focal samples. Although most males were 
only observed on one day (8), some males were observed on two (6), three (2), four (4), five (1), or seven (2) separate days. We collected focal sample data for a total of $30 \mathrm{~h}$ of observation. Data collected included territory location, initial and final group type, group composition, female and chulengo activity (when present), initial and final habitat type, time of day, and timed behavioral activities.

Behaviors were divided into seven major activity categories: resting (all inactive periods not associated with a second behavior except ruminating), bathing (any dust bath or selfgrooming), foraging (feeding bouts), alert (all scanning of surroundings or staring at other animals/objects in the area), aggression (all aggresive behavior towards other guanacos), moving (walking or running), and miscellaneous (all other observed activities). Resting could be distinguished from alert in that focal animals were not actively scanning or staring but were instead almost randomly, in intensity and direction, viewing their environment. Multiple behaviors were recorded if observed at the same time, but the dominant behavior was used for timing. During aggression periods, the sex of other guanacos involved was recorded. Moving did not include any walking or running that was associated with a second behavior (e.g., if a male was walking towards another guanaco aggressively, then the behavior was categorized as aggression). The category "miscellaneous" included such behaviors as scratching, nonaggressive defecation, and alertness to the observer (that primarily occurred at the start of observations).

The region's habitat is characterized by open areas with long-range visibility. Habitat types were categorized based on dominant vegetation and topography. Vegetation types included calafate (Berberis buxifolia), mata negra (Senecio patagonicus), mata barrosa (Mulinum spinosum), coiron (Festuca gracillana), and meadow-like "vegas" (dominated by Holcus lanatus and Hordeum comosum; Pisano 1974, Ortega \& Franklin 1988, Lawrence 1990). Of these vegetation types, mata negra has the most reduced visibility and vegas the least (personal observation). The topography was classified as hilltop, hillside, or flat. Data was analyzed using analyses of variance (ANOVA) with
Bonferroni adjustments for multiple tests with SAS (SAS Institute 1990). Some males were observed multiple times, so we nested the behavioral effects by individual males. Because there was no significant difference in behaviors between males, each focal sample was treated independently in some analyses. For example, to test the effects of habitat type, each focal sample was treated as an independent sample for analyses because individual males used multiple habitats within their territories. Results are given as means \pm SD .

We looked at the effect of social territory condition (solo versus family-group territorial males during the entire focal sample) and the proportion of time spent per activity by ANOVA. During nine focal samples of six different territorial males, the focal male changed social type. These focal samples were excluded from analysis of social group type. Seven males were observed as solo territorial males and family group males during separate focal samples. We evaluated aggression behavior more closely, and assessed how sex of the other guanaco involved influenced the aggressive behavior of the focal guanaco. We further categorized males into one of three classes based on the number of reproductiveaged females present. Only behavioral observation periods during which the number of females present remained constant were used in the analysis. Males were observed with an average of $1.6 \pm 4.4$ reproductive-aged females present. For analyses, male observations were classified as: (1) solo territorial males with no females present; (2) family-group territorial males with 1-6 females present; or (3) family group territorial males with more than six females present. When females were present, their activity was recorded but not timed. For those observations with females present, we calculated the proportion of observations when each specific activity was recorded.

Territorial male activity budgets were further analyzed by total number of guanacos present, including the territorial male, females, yearlings, and chulengos. The average group size for all territories observed was $3.4 \pm 6.1$. We categorized male territory locations as having $\leq 2,3-9$, or $>9$ total guanacos present.

We placed observation periods into three time categories: morning from 09:30-12:00 h, mid-day from 12:00-14:00 $\mathrm{h}$, and afternoon 
from 14:00-16:00 $\mathrm{h}$. We also analyzed the behavioral time budgets of territorial males by the dominant habitat type, the sex of the second guanaco involved in all aggression activities, and age of the territorial male. For statistical significance we accepted P-values for ANOVA tests at $\leq 0.007$ based on the Bonferroni adjustment. This value was determined by dividing the standard 0.05 P-value by the number of independent tests $(\mathrm{n}=7)$ for each behavior.

RESULTS

There were significant differences in the time spent per activity within all territorial male observations $\left(\mathrm{F}_{6,833}=237, \mathrm{P}<0.001, \mathrm{n}=120\right)$.
Territorial males spent most of their time foraging $(65 \%)$. Alert $(14 \%)$ and resting (12 $\%)$ were also observed regularly, but for less time than foraging (Fig. 1).

We found no difference in the activity time budgets of individual males or between solo territorial males and family-group territorial males (Table 1). The time spent in each of the seven activities did not vary between solo and family-group territorial males $(\mathrm{P}>0.007$, Table 1). There was also no effect of the total number of females present on the proportion of time spent per activity $(\mathrm{P}>0.007$, Table 1$)$.

In the territorial observations with females present $(n=46)$, females were mainly found foraging (in $89 \%$ of observations) and resting (in $43 \%$ of observations). Females were also found alert (26\%), followed by moving $(15 \%)$,

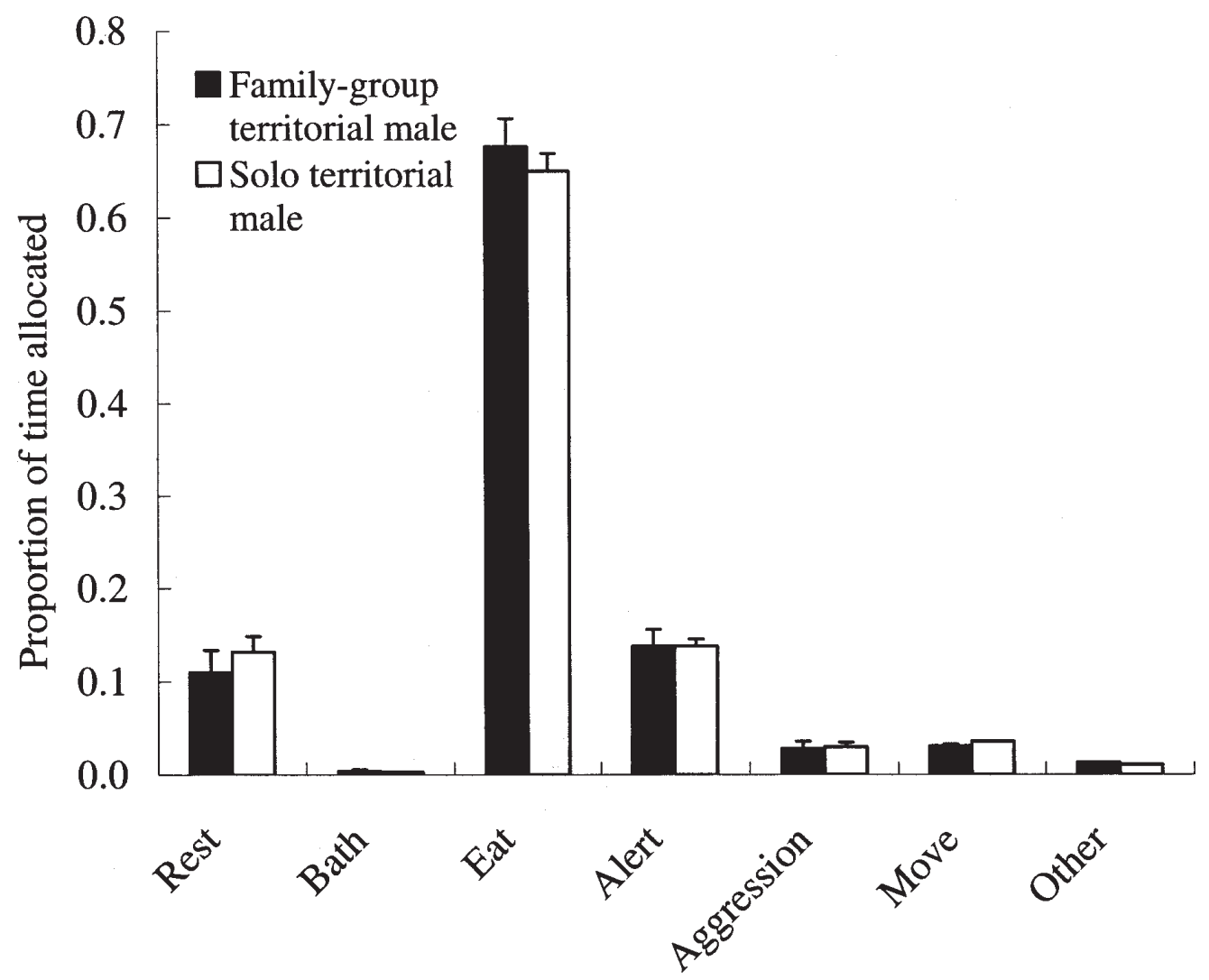

Fig. 1: Activity time budget for territorial males that maintained a constant social group type during observations as either solo $(n=68)$ or family-group $(n=39)$ between October 1998 and March 1999, at Torres del Paine National Park, Chile. There were no significant differences in behavior based on social type.

Presupuesto de actividad de machos territoriales que mantenian un grupo social constante durante las observaciones tanto solo $(n=68)$ como en grupos familiares $(n=39)$ entre octubre 1998 y marso 1999, en el Parque Nacional Torres Paine, Chile. No hubo diferencias significativas en comportamiento basado en el tipo social. 
aggression (11\%), miscellaneous (9\%), and bathing $(7 \%)$.

We found no significant effect of overall group size on activity time budgets for males ( $\mathrm{P}$ $>0.007$, Table 1). There was also no effect of time of day on the activity time budgets of male guanacos $(\mathrm{P}>0.007$, Table 1$)$ or based on the age of the territorial male $(\mathrm{P}>0.007)$.

Territorial males were observed in a variety of habitats, but most frequently were found at vegas (54\% of the time, Table 2). There was a significant effect of habitat type on the time spent in aggression $\left(\mathrm{F}_{2,71}=15.17\right.$, $\mathrm{P}<0.0002, \mathrm{n}=81$; Table 1), with most aggressive encounters occurring on mata barrosa hilltops $(38 \%)$. No aggression behavior occurred in calafate flat areas, vegas and coiron hilltops. There was a significant effect of habitat type on the time budget for miscellaneous activity $\left(\mathrm{F}_{2,71}=6.17, \mathrm{P}<0.004\right.$, $\mathrm{n}=81$; Table 1 ), with this class of activity occurring mostly on mata barrosa hilltops (10 $\%)$. Males spent no time in miscellaneous activities while in mata barrosa and coiron flat areas. There was no significant effect of habitat type on the proportion of time resting, bathing, foraging, alert or moving $(\mathrm{P}>0.007$, Table 1).

Aggression behavior was observed in 16 of the 23 territorial males during 31 of the 120 focal sample periods. There was no significant difference in the time budgeted for any of the activities based on the sex of the other guanaco involved ( $\mathrm{P}>0.007$, Table 1).

\section{DISCUSSION}

Territorial male guanacos spent most of their time foraging $(65 \%)$, followed by alert $(14 \%)$ and resting (12\%). Jurgensen (1985) also found that territorial male guanacos within Torres del Paine spent a large amount of time foraging $(54 \%)$. Similar behavioral patterns have been observed in other territorial ungulate species, including the bontebok (Antidorcas marsupialis, David 1978) and pronghorn (Antilocapra Americana, Byers 1997).

Our prediction, that family-group territorial males would have different activity time budgets than solo territorial males was not supported. In fact, time budgets of territorial males did not vary with individual, social group type, the age of the territorial male, the number of females present, or the total number of guanacos present.

Furthermore, our prediction that the time budgeted for alert and foraging behaviors would vary between family-group and solo territorial males, was not supported. Although Lagory (1986) found that white-tailed deer (Odocoileus virginianus) groups did not use different anti-predator strategies based on group size, many polygynous ungulates decrease the amount of time each individual spends being vigilant as group size increases

\section{TABLE 1}

F-statistics from ANOVA for the proportion of time spent by territorial male guanacos in each activity. All observations occurred in Torres del Paine National Park, Chile, during the 1998-1999 territorial season. See methods section for explanation of categories

Valores de $\mathrm{F}$ de los análisis de varianza para la proporción de tiempo usada por guanacos machos territoriales en cada actividad. Estudio realizado en el Parque Nacional Torres Paine, Chile, durante la temporada territorial 1998-1999

\begin{tabular}{lcccccccc}
\hline Factor or comparison & $\mathrm{n}$ & Resting & Bathing & Foraging & Alert & Aggression Moving Miscellaneous \\
\hline Male ID (nested) & 23 & 1.05 & 0.53 & 1.42 & 2.25 & 0.86 & 1.98 & 1.06 \\
Family-group versus solo & 21 & 0.03 & 0.26 & 0.06 & 0.00 & 0.03 & 0.16 & 0.02 \\
Females present & 22 & 0.02 & 0.31 & 1.44 & 2.94 & 0.30 & 0.27 & 2.01 \\
Total group size & 22 & 0.15 & 0.72 & 1.50 & 2.87 & 0.25 & 0.24 & 2.17 \\
Time of day & 23 & 0.22 & 1.89 & 2.29 & 1.98 & 4.09 & 1.46 & 0.77 \\
Habitat & 81 & 0.30 & 0.04 & 0.39 & 0.22 & $15.17 *$ & 0.18 & $6.17 *$ \\
Aggression & 16 & 0.85 & 1.53 & 0.17 & 0.08 & 0.98 & 0.63 & 1.48 \\
\hline
\end{tabular}

$* \mathrm{P}<0.007$ 
(Jarman 1974). For example, most individuals within pronghorn and white-tailed deer populations decrease the amount of time alert as group size increases (Lipetz \& Bekoff 1982, Lagory 1986). Female and juvenile mountain goats (Oreamnos americanus) not only decrease the amount of time alert, but also increase the amount of time spent feeding as group size increases (Risenhoover \& Bailey 1985). For these species, altering individual time budgets based on group size increases foraging efficiency without decreasing the overall time spent alert because the group compensates for the individual differences.

However, Maher (1991) found that pronghorn males decrease the time spent feeding once rutting season begins and previously solitary males are found with females. Under these circumstances, pronghorn males spend more time in behaviors related to attracting a mate and mating (Maher 1991). This time spent interacting with other conspecifics can lead to a decrease in the amount of time spent foraging (Risenhoover \& Bailey 1985). Some ungulates, such as red deer (Cervus elaphus), are more frequently interrupted by conspecifics when group size increases (Clutton-Brock et al. 1982). Individuals in a group of moose increase the time spent alert as group size increases (Molvar \& Bowyer 1994). In guanacos, it is possible that there was no effect of social group type on the time spent alert because solo territorial males may spend more time alert to potential predators, whereas family-group territorial males may spend more time alert to conspecifics.

If time spent alert was influenced by perceived predation risk, guanacos in habitats where pumas are more successful hunters would behave differently than guanacos in more open habitats, where pumas (puma concolor) are less successful hunters. Mountain goats increase their time alert as they feed closer to timberline, an area of higher predation risk (Romeo \& Lovari 1996). Similarly, Goldsmith (1990) noted that female pronghorn vigilance behavior increased in habitats with low visibility (tall vegetation). Although pumas in Torres del Paine National Park are most successful when hunting guanacos from elevated and hidden positions (Wilson 1984), there was no difference in alert behavior between the habitat types where territorial males were observed.

It should be noted that our study did not differentiate between anti-predator alert behavior (vigilance) and alert behavior directed towards guanacos and other non-predator species. Further observations that tease out these different strategies are needed.

We found no difference in behavioral time budgets based on the time of day. The guanaco's only predator, the puma, is most active at dawn and dusk (Franklin et al. 1999). We had hypothesized that males would decrease the time spent on non-alert behaviors, such as bathing and resting, in the early time

TABLE 2

Dominant habitat and topography used by territorial male guanacos during the 1998-1999 territorial season. The total number of times males remained within each habitat are shown for focal samples in Torres del Paine National Park, Chile $(\mathrm{n}=81)$

Hábitat y topografía dominantes usados por guanacos machos territoriales durante la temporada territorial del 1998-1999. Número total de veces que los machos permanecieron en cada hábitat, basado en muestreo focal en el Parque Nacional Torres del Paine, Chile $(\mathrm{n}=81)$

\begin{tabular}{lccc}
\hline \multirow{2}{*}{ Habitat } & \multicolumn{2}{c}{ Topography } \\
\cline { 2 - 4 } & Hillside & Hilltop & Flat area \\
\hline Mata Barrossa & 13 & 1 & 6 \\
Mata Negra & 2 & - & - \\
Calafate & - & - & 2 \\
Coirón & 4 & - & 8 \\
Vega & - & 2 & 43 \\
\hline
\end{tabular}


period because of their increased vulnerability to predation at this time. However, we found no relationship between the time of day and activity. Because pumas are more likely to select chulengos as prey (Bank \& Franklin 1998, Franklin et al. 1999, Bank et al. 2002), it is possible that females with young guanacos would be more likely to exhibit variation in alert behavior by time of day than males.

There were differences in male territorial guanaco behaviors based on habitat type. Males spent more time in aggression and miscellaneous activities on mata barrosa hilltops. This shrub rarely grows taller than 0.5 $\mathrm{m}$ (Pisano 1974). Use of these open hilltop areas for aggressive behaviors could be advantageous to the males. From a hilltop, guanacos in this low-lying vegetation have an extensive view and are relatively safe from ambush attacks by pumas (Iriarte 1991, Bank \& Franklin 1998). Males can invest more time in non-alert activities without increasing predation risks because pumas are typically found in areas with trees or high plant cover density ( $>3$ $\mathrm{m}$ tall; Bank \& Franklin 1998, Franklin et al. 1999).

Although a mata barrosa hilltop does not provide females with a high quality food resource (Lawrence 1990), it could act as geographically important male display grounds during fights. It is possible that other males observe these fights and compare their own ability based upon these observations. David (1978) noted that aggressive chasing of other males by territorial springbok is a method of advertising their territorial status. Some red deer establish territories with lower quality swards in areas that females use as routes to better territorial habitats (Carranza 1995). Although hilltops may not be on direct routes used by female guanacos, aggressive behavior between two males on hilltops could provide female guanacos with knowledge of the male territories. From a hilltop, territorial males can still see the rest of their territory while engaged in aggressive behaviors.

It is unclear if hilltops are frequently used as territorial boundaries. If the hilltop represents a territorial edge, then aggressive behavior may occur more frequently within this habitat because males may spend more time defending their boundaries. It seemed that aggression between two male guanacos occurred throughout territories but future studies are needed to elucidate the relationship between space use and aggression.

Family-group and solo territorial male guanacos did differ in the amount of time budgeted for miscellaneous behaviors. The biological implications of this difference are currently unclear. Future behavioral studies of territorial guanacos should focus on quantifying behaviors within the miscellaneous category to elucidate the cause.

In many territorial mammals, there are differences in male behavioral patterns that influence an individual's mating success (Rachlow et al. 1998). In this study, variation in reproductive success rates of territorial male guanacos could not be explained by individual behavioral time budgets. Territorial behavior of other male ungulates is frequently used to attract and secure mates (Owen-Smith 1977, David 1978, Gosling 1986, Rachlow et al. 1998), but in this population of guanacos, males attract mates solely through resourcedefense rather than through differences in behavior. Even though some males have an opportunity to change social group, our prediction that solo territorial males would behave differently than family-group type males was not supported. The habitats in which male guanacos establish territories act as the main resource to attract females (Franklin 1983). Although some studies have cast doubt on whether female choice is based solely on a male's defended resources (Ostfeld 1987, Balmford et al. 1992), the lack of behavioral differences between mating and non-mating males favors the argument that resources act as a strong attractant for female guanacos.

\section{ACKNOWLEDGEMENTS}

We thank the Chilean National Forestry and Park Service (CONAF) and the park service employees within Torres del Paine National Park for their cooperation and assistance. We also thank I.M. Ortega, O. Guineo, and M. Álvarez for logistical support. S. Laws, M. Emht, M. Montag, S. Wlodarski, and M. Dougherty provided field assistance. P. Dixon, B. Snyder, and R. Fletcher provided statistical assistance. We thank B. Bowen, C. Vleck, and two anonymous reviewers for reviewing the 
manuscript. We also thank I.M. Ortega for assistance with Spanish translation and reviewing the manuscript. Patagonia Research Expeditions (through Hidden Corners and the University of Connecticut) supported this study.

\section{LITERATURE CITED}

ALTMANN J (1974) Observational study of behavior: sampling methods. Behaviour 49: 227-267.

BALMFORD A, AM ROSSER \& SD ALBON (1992) Correlates of female choice in resource-defending antelope. Behavioral Ecology and Sociobiology 31: 107-114.

BANK MS, RJ SARNO, NK CAMPBELL \& WL FRANKLIN (2002) Predation of guanacos (Lama guanicoe) by southernmost mountain lions (Puma concolor) during a historically severe winter in Torres del Paine National Park, Chile. Journal of Zoology, London 258: 215-222.

BYERS JA (1997) American pronghorn: social adaptations and the ghost of predators past. University of Chicago Press, Chicago, Illinois, USA. 300 pp.

CARRANZA J (1995) Female attraction by males versus sites in territorial rutting red deer. Animal Behaviour 50: 445-453

COLMAN JE, C PEDERSEN, D $\varnothing$ HOLAND, $\varnothing$ HOLAND, SR MOE \& E REIMERS (2001) Twenty-four hour feeding and lying patterns of wild reindeer Rangifer tarandus in summer. Canadian Journal of Zoology 79: 2168-2175.

CLUTTON-BROCK TH, FE GUINNESS \& SD ALBON (1982) Red deer behavior and ecology of two sexes. The University of Chicago Press, Chicago, Illinois, USA. 378 pp.

DAVID JHM (1978) Observations on territorial behavior of springbok, Antidorcas marsupialis, in the Bontebok National Park. Zoologica Africana 13: 123-141.

EMLEN ST \& LW ORING (1977) Ecology, sexual selection, and the evolution of mating systems. Science 197: 215-222.

ESTES RD (1991) Behavior guide to African mammals. The University of California Press. Berkeley, California, USA. $611 \mathrm{pp}$.

FRANKLIN WL (1982) Biology, ecology, and relationship to man of the South American Camelids. In: Mares MA \& HH Genoway (eds) Mammalian biology in South America: a symposium held at the Pymatuning Laboratory of Ecology: 457-489. University of Pittsburgh, Linesville, Pennsylvania, USA.

FRANKLIN WL (1983) Contrasting socioecologies of South America's camelids: the vicuna and guanaco. In: Eisenberg JF \& D Kleiman (eds) Advances in the study of mammalian behavior: 573-629. Special Publications No. 7, American Society of Mammalogists, Shippensburg, Pennsylvania, USA.

FRANKLIN WL \& WE JOHNSON (1994) Hand capture of newborn open-habitat ungulates: the South American guanaco. Wildlife Society Bulletin 22: 253-259.

FRANKLIN WL, WE JOHNSON, RJ SARNO, \& JA IRIARTE (1999) Ecology of the Patagonia puma Felis concolor in southern Chile. Biological Conservation 90: 33-40.

GOLDSMITH AE (1990) Vigilance behavior of pronghorns in different habitats. Journal of Mammalogy 71: 460-462.

GOSLING LM (1986) The evolution of mating strategies in male antelopes. In: Rubenstein DI \& RW Wrangham (eds) Ecological aspects of social evolution: birds and mammals: 244-281. Princeton University Press, Princeton, New Jersey, USA.

IRIARTE JA, WE JOHNSON, \& WL FRANKLIN (1991) Feeding ecology of the Patagonia puma in southernmost Chile. Revista Chilena de Historia Natural 64: 145-156

JARMAN PJ (1974) The social organization of antelope in relation to their ecology. Behaviour 48: 215-267.

JURGENSEN TE (1985) Seasonal territoriality in a migratory guanaco population. Master of Science Thesis, Iowa State University, Ames, Iowa, USA. $54 \mathrm{pp}$.

LAGORY KE (1986) Habitat, group size, and the behaviour of white-tailed deer. Behaviour 98: 168179.

LAWRENCE RK (1990) Influences on habitat selection and group size in guanacos of Torres del Paine National Park, Chile. Master of Science Thesis, Iowa State University, Ames, Iowa, USA. 119 pp.

LIPETZ VE \& M BEKOFF (1982) Group size and vigilance in pronghorns. Zeitschrift für Tierpsychologie 58: 203-216.

MAHER CR (1991) Activity budgets and mating system of male pronghorn antelope at Sheldon National Wildlife Refuge, Nevada. Journal of Mammalogy 72: 739-744.

MOLVAR EM \& RT BOWYER (1994) Costs and benefits of group living in a recently social ungulate: the Alaskan moose. Journal of Mammalogy 75: 621-630.

ORTEGA IM \& WL FRANKLIN (1988) Feeding habitat utilization and preference by guanaco male groups in the Chilean Patagonia. Revista Chilena de Historia Natural 61: 209-216.

ORTEGA IM \& WL FRANKLIN (1995) Social organization, distribution, and movements of a migratory guanaco population in the Chilean Patagonia. Revista Chilena de Historia Natural 68: 489-500.

OSTFELD RS (1987) On the distinction between female defense and resource defense polygyny. Oikos 48: 238-240.

OWEN-SMITH RN (1977) On territoriality in ungulates and an evolutionary model. The Quarterly Review of Biology 52: 1-38.

PISANO E (1974) Estudio ecológico de la región continental sur del área andino patagónica. II. Contribución a la fitogeografía de la zona del Parque Nacional Torres del Paine. Anales del Instituto de la Patagonia (Chile) 5: 59-104

RACHLOW JL, EV BERKELEY \& J BERGER (1998) Correlates of male matingstrategies in white rhinos (Ceratotherium simum). Journal of Mammalogy 79: 1317-1324.

RISENHOOVER KL \& JA BAILEY (1985) Relationship between group size, feeding time, and agnostic behaviour of mountain goats. Canadian Journal of Zoology 63: 2501-2506.

ROMEO G \& S LOVARI (1996) Summer activity rhythms of the mountain goat Oreamnos americanus (de Blainville, 1816). Mammalia 60: 496-499.

SAS INSTITUTE (1990) SAS/STAT user's guide: version 6. Fourth edition. SAS Institute Inc., Cary, North Carolina, USA. 1686 pp.

SHI J, RJM DUNBAR, D BUCKLAND \& D MILLER (2003) Daytime activity budgets of feral goats (Capra hircus) on the Isle of Rum: influence of 
season, age, and sex. Canadian Journal of Zoology 81: 803-815.

TORRES H (1985) Guanaco: distribution and conservation of the guanaco. IUCN/SSC South American Camelid Specialist Group Publication, Special Report No. 2, Gland, Switzerland. 37 pp.

TORRES H (1992) South American Camelids: an action plan for their conservation. IUCN/SSC South American Camelid Specialist Group Publication, Gland, Switzerland. $58 \mathrm{pp}$

Associate Editor: Luis Ebensperger

Received February 26, 2004; accepted September 7, 2004
WALTHER FR, EC MUNGALL \& GA GRAU (1983) Gazelles and their relatives a study in territorial behavior. Noyes Publications, Park Ridge, New Jersey, USA. 239 pp.

WILSON W (1984) Puma predation on guanacos in Torres del Paine National Park, Chile. Mammalia 48: 515-522.

YOUNG JK \& WL FRANKLIN (2004) Territorial fidelity of territorial male guanacos in the Patagonia of southern Chile. Journal of Mammalogy 65: 72-78. 